\title{
RESIDENTIAL PATTERNS OF IN-MIGRANTS IN RĪGA
}

\section{lekšzemes migrantu apdzīvojuma iezīmes. Rīgas piemērs}

\author{
Jānis Krūmiṇš, Māris Bērziṇš, Zaiga Krišjāne \\ University of Latvia, Faculty of Geography and Earth Sciences \\ janis.krumins2@lu.Iv
}

\begin{abstract}
Population distribution and internal migration are closely related to each other and are sensitive to changes that are evoked by various political, economic and social processes. The distribution of population sub-groups has been mostly studied in post-socialist cities in relation to ethnic and socioeconomic segregation. However, the importance of internal migration has been less investigated. This paper uses 2000 and 2011 census data and aims to evaluate the residential patterns of in-migrants in the neighbourhoods of Rìga. Key findings have revealed that levels of in-migrant concentration are higher in the inner city neighbourhoods, whereas the degree of activity is considerably lower in the city outskirts. Comparison of 2000 and 2011 patterns show a decrease of in-migration activity for more than half of the neighbourhoods, with the exception of numerous panel housing estates to the east from the inner city.
\end{abstract}

Keywords: internal migration, population distribution, Rīga.

\section{Introduction}

Political, economic and social transformations since the collapse of state socialism in Central and Eastern Europe (CEE) have been crucial in the changing nature of population distribution and settlement patterns. These changes have been most evident in urban areas of the region, where such development has drawn scholarly and public attention to the topic of socio-spatial differentiation in postsocialist cities. Numerous researches have been conducted in relation to urban social inequalities and have also paid attention to mobility related processes such as suburbanisation and gentrification, mostly addressing population differentiation among city neighbourhoods (e.g. Brade et al. 2009; Kovacs and Herfert 2012; Kährik and Tammaru 2010; Temelová et al. 2011; Gentile et al. 2012). Another body of literature that is closely related to population distribution has tried to address the issue of social segregation in the cities of CEE, mostly trying to study either the ethnic or socio-economic intra-urban geography of the total population (e.g. Gentile and Tammaru 2006; Marcińczak et al. 2012; Marcińczak et al. 2014; Krišjāne and Bērziṇš 2014; Tammaru et al. (eds.) 2015). However, the linkage between internal migration and population distribution has been less studied.

According to Central Statistical Bureau data for 2018, Rīga, the capital and largest city of Latvia, housed 637971 residents or approximately one third of the total national population. It can be considered as the most important urban centre of Latvia, and holds significant primacy in the country's political, social and cultural functions. The population of Rìga is reported to be almost eight times higher than in the $2^{\text {nd }}$ most populated urban centre - Daugavpils. Although, the importance of Riga is unambiguous, the total population of the city has decreased by $16.7 \%$ during the period from 2000 to 2017. Mobility processes can be considered as the main cause for such changes. Respectively, Rīga has lost $11 \%$ of its population at the expense of 
migration, whereas the decline in relation to natural balance has been less significant ($5.7 \%$ ). Although, this can partially be explained with increased international migration outflows (especially from 2008 to 2011), the most specific contributor to steady population decline in Rīga can be attributed to internal migration and its resulting process - residential suburbanisation. As a result, Rīga had been losing population in exchange with its suburban hinterland - Pierīga; whereas, the capital city is gaining population at the expense of all other statistical regions (Vidzeme, Zemgale, Kurzeme and Latgale). Such inter-regional relations also reflect on internal migration numbers that define Rìga as the main hub of internal migration activity. In 2016, $29.6 \%$ of all internal migration flows were related to Rīga.

Therefore, internal migration can be considered as very significant in re-shaping population distribution in the post-socialist space (e.g. Kontuly and Tammaru 2006; Krišjāne and Bērziņš 2012; Novotný and Pregi 2015), and this study aims to evaluate residential patterns of in-migrants in the neighbourhoods of Riga by examining 2000 and 2011 Population Census rounds. Location quotient (LQ) is used as a descriptive measure to assess the concentration of internal migrants within the neighbourhoods of Rīga.

\section{Data and Methods}

The data used in this study was drawn from the 2000 and 2011 population census rounds provided by the Central Statistical Bureau and focussed solely on Rìga city. The data on internal migrants to Riga was thus derived. The available dataset is the most reliable source of information for the population composition in Latvia. However, the census data categorises persons as migrants only for a limited timespan. Thus, according to the census data collection specifics, a person was considered an internal migrant to Rīga if the following criteria applied:

- In 2000, on answering the question about their place of residence one year before the Census had been taken (as of 31 March 1999), residents had chosen the "Other" option, and later indicated any other municipality of residence except Rīga.

- In 2011, on answering the question about whether the person lived in the same place of residence one year before the Census had been taken (as of $1 \mathrm{March}$ 2010), the resident had replied negatively (No - meaning that not only the dwelling had been changed, but also the municipality), and in the next question had indicated their previous municipality of residence (not Rìga). 


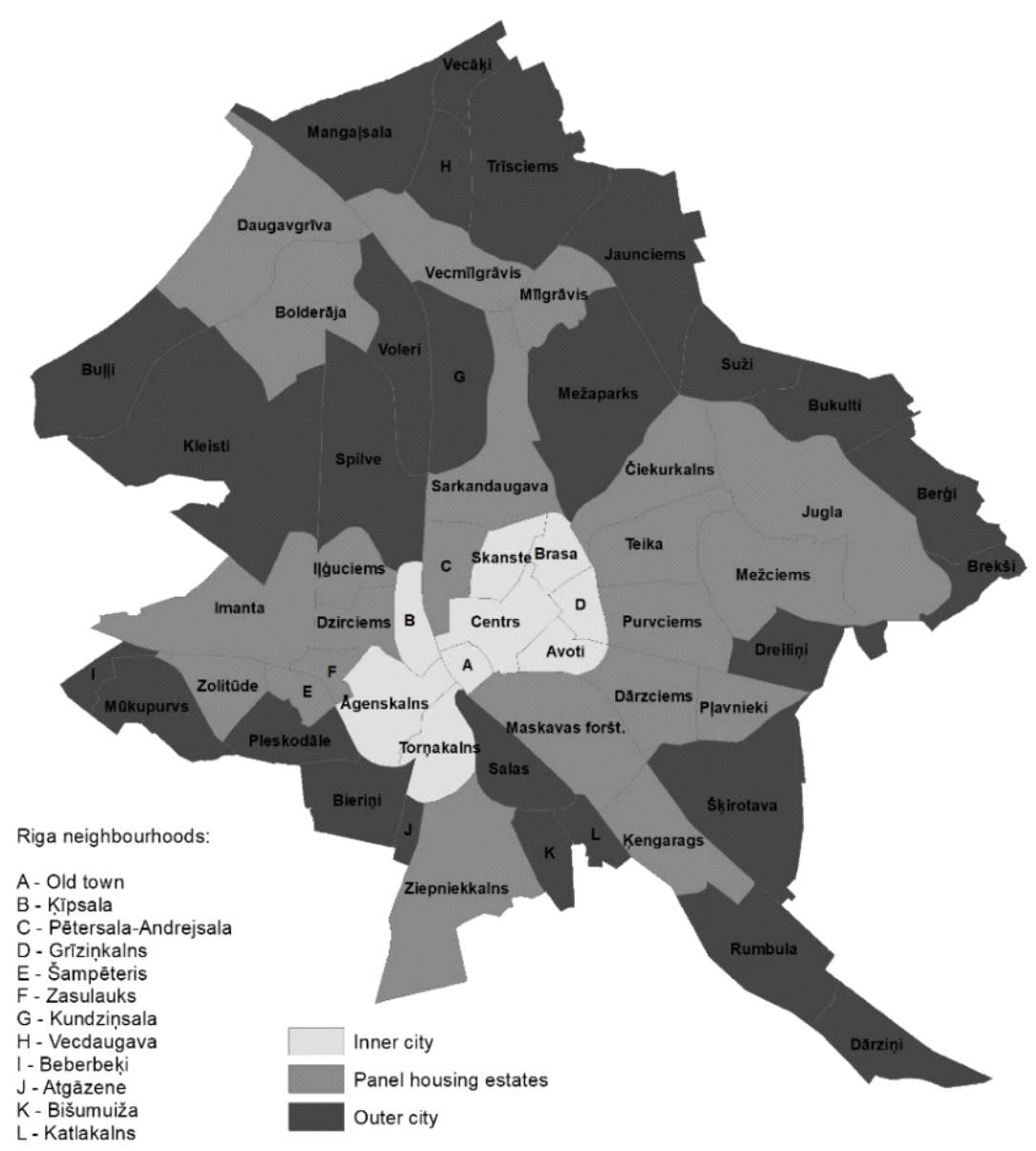

Figure 1. Map of neighbourhood units in Rīga divided into urban zones (authors' figure based on Riga City Council data)

Thus, 8012 residents in 2000 (1.25\% of the total city population), and 5012 residents in $2011(0.8 \%)$ were categorised as internal migrants to Rìga. Migration activity in the latter case was considerably lower due to the effects of the global economic crisis which resulted in higher international migration activity. In order to gain a better understanding, the neighbourhood residential patterns in the results chapter were studied using the division of Rìga into 3 distinctive urban zones (Figure 1) that are based on historical development and general patterns of built-up areas following the boundaries of neighbourhoods. Such division can be found in a great majority of cities in CEE (e.g. Sýkora 2009; Kovács and Herfert 2012). The zones are as follows: 1) inner city; 2) panel housing estates; 3) outer city.

The next step included the conversion of census data to cells of a hexagonal grid (see Reardon and O'Sullivan 2004; Brown and Chung 2006). The grid consists of 2002 cells that are fully or partially within the borders of Rīga and occupy approximately $16.5 \mathrm{ha}$. In total, there were 685 cells with registered in-migration activity in at least one of the censuses. With such data, it is possible to map in detail where members of a particular social strata were concentrated in Rīga. A previous study by Krišjāne et al. (2015) had used a similar methodology to map the occupational and ethnic composition of the population in the neighbourhoods of Riga. 
The in-migrant spatial data was analysed using the Geo-Segregation Analyzer 1.2, and calculated as location quotients (LQ). This analytical statistic measure was used to illustrate spatial patterns of concentration (see Brown and Chung 2006). In this case, it shows the representation of in-migrants within a spatial unit in comparison to the city average (3.5). Therefore, 3 gradation categories were chosen for visual representation:

- LQ $<1.5$ - to highlight spatial units with rather low in-migrant representation;

- $1.5<\mathrm{LQ}<3.5$ - to emphasize spatial units with neutral in-migrant representation similar to the city average;

- $\mathrm{LQ}>3.5$ - to distinguish spatial units with high in-migrant representation above the city average rate.

\section{Results}

The intra-urban geography of internal migrant groupings has similar patterns with higher representation in the neighbourhoods closer to the city centre for both 2000 and 2011 (Figure 2). Respectively, neighbourhoods such as Centrs, Brasa, Grīzinkalns and Avoti are located in the inner city where the proportion of rental dwellings is usually higher. Another cause for such an in-migration pattern in the central part could be explained with a typically younger population composition. Census data shows that 11 neighbourhoods had a positive or neutral average age of population in 2011 in comparison to 2000. Three of the four afore-mentioned inner city neighbourhoods were among these, whereas one (Grīziṇkalns) has a slightly negative difference. In addition, inner city neighbourhoods are very attractive for residents previously or currently involved in student migration. Thus, even though these neighbourhoods are attractive to in-migrants; they also witness higher outmigration by way of both residential mobility and out-migration to Pierīga.

High, and on some occasions, above average concentrations of in-migrants are characteristic to neighbourhoods with a considerable share of high-rise standardised and pre-fabricated panel housing estates such as those at Purvciems, Teika, Imanta, Ilıguciems, Vecmīlgrāvis, Jugla, Kengarags and Sarkandaugava. Even though, these neighbourhoods can be characterised as being with above average in-migration activity, there has been neither increase or decrease of in-migrant representation in certain spatial units in 2011. High concentrations (>3.5) can be explained with the status of panel housing estates in the housing market. In this case, the dwellings in these neighbourhoods are more affordable and thus more in demand by in-migrants. Meanwhile, the changing pattern of panel housing estates can also be interpreted as a result of the global economic crisis that affected the conditions of the housing market. Nevertheless, panel housing neighbourhoods still maintained their status quo during the 2000s as an economically attractive destination for potential in-migrants. Such attractiveness can be linked with the fact that Soviet-era standardised apartment buildings, which are highly evident in the afore-mentioned neighbourhoods, house a 
considerable proportion of urban dwellers. As the research of Krišjāne et al. (2015) observed, approximately $3 / 4$ of Rīga's urban population lived in panel housing estates in both 2000 and 2011. In 2011, the population had experienced a slight increase. By contrast, the inner city population had decreased.
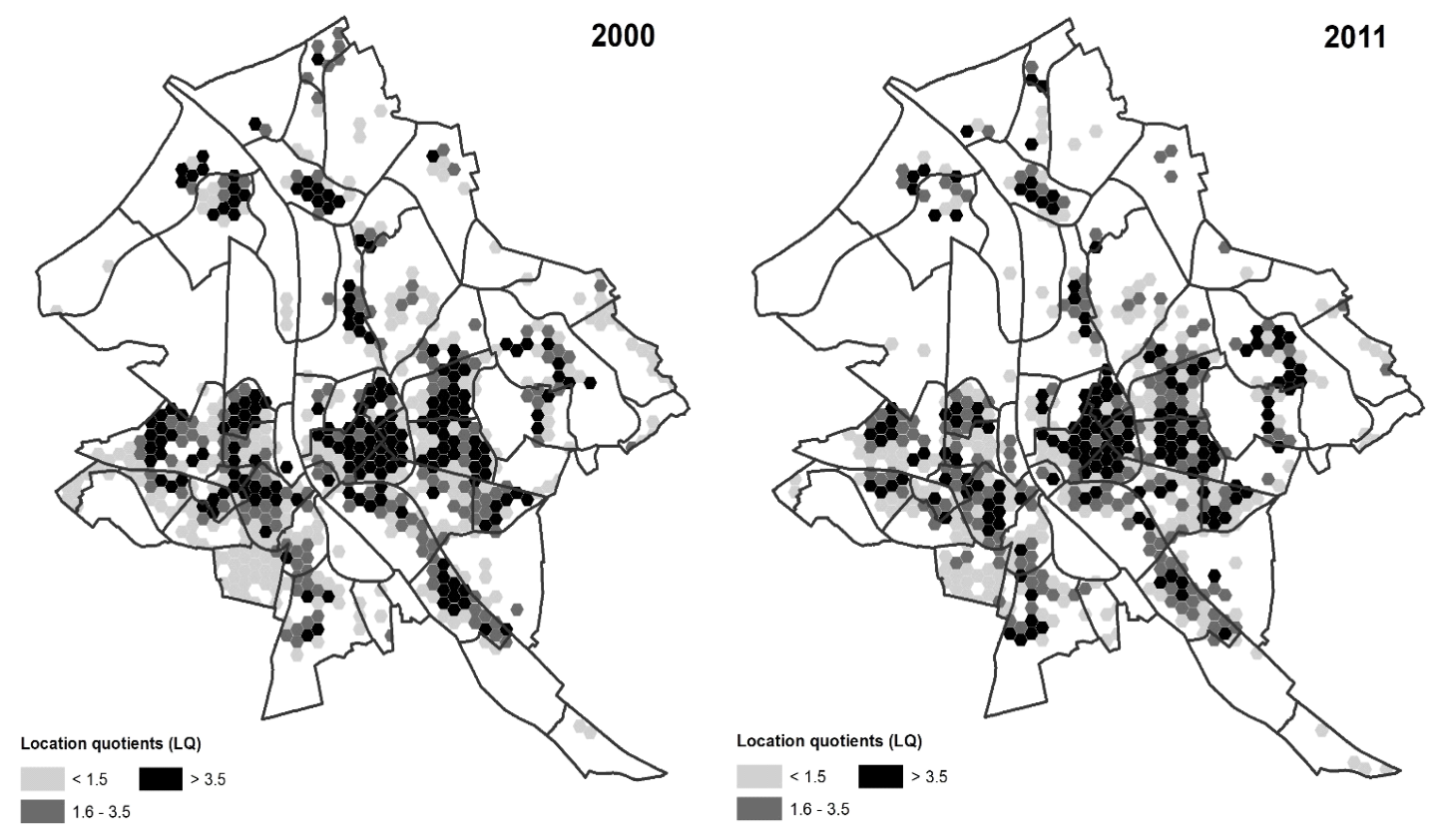

Figure 2. Internal migrant representation (LQ) in Rīga neighbourhoods in 2000 and 2011 (authors' figure based on Population Census 2000 and 2011 data)

Comparison between 2000 and 2011 in-migrant concentration patterns show a higher overall representation in 2000. More than half of the 58 neighbourhoods (35) in Rīga have lower concentrations in their spatial units, whereas 18 territorial units have experienced increase in the representation of in-migrants from other municipalities. Finally, 6 neighbourhoods remained unchanged in terms of concentration. Interestingly, Brasa and Skanste are the only inner city neighbourhoods to witness an increase. In the former, the neighbourhood of Brasa is characterised by lower inmigration flows, that have slightly increased in the eastern part. In the latter case, Skanste has been the only inner city neighbourhood with a positive population increase from 2000 to 2011. This phenomenon may mostly be explained with the numerous constructions of high-rise modern residential buildings (see Treija and Bratuškins, 2014) in the area that attracted in-migration flows.

Panel housing estates show similar patterns of in-migrant representation. Out of 22 neighbourhoods only 7 had a higher concentration of in-migrants than in 2000 . These include Jugla, Mežciems, Purvciems, Dārzciems, Pḷavnieki, Ziepniekkalns and Zolitūde. The first five are located to the east of the city centre and are bordering each other. Interestingly, previous research on the distribution of occupational groups in 
Rīga (Krišjāne et al. 2015) found that there has been an increase in concentration of the highest socio-economic group and the area of higher representation of this socioeconomic subgroup has extended eastwards. Therefore, both cases could be linked to the attractiveness of these neighbourhoods in the housing market and the presence of the economic crisis.

Outer city neighbourhoods have a lower population density, and thus have considerably lower in-migration flows than do the other two urban zones. Nonetheless, in terms of migrant concentration, eight neighbourhoods have witnessed increase. Those include Bieriņi, Dārziņi and Dreiliṇi - the areas with housing and residential patterns similar to municipalities within the suburban ring outside of the Rìga city borders.

\section{Conclusion}

In this paper it has become evident how residential patterns of in-migrants have evolved and transformed through analysis of the 2000 and 2011 Census data. Results have shown that the intra-urban geography of internal migrants had similar patterns with higher representation in the neighbourhoods closer to the city centre for both years. This could well be explained by the fact that the proportion of rental dwellings in these areas is usually higher. However, even though the inner city is attractive to inmigrants; it also witnesses higher out-migration.

High and above average concentrations of in-migrants are characteristic to panel housing estates. High concentrations can be explained by the affordability of dwellings in high-rise residential buildings that are located in these areas, and are thus more in demand by in-migrants. Meanwhile, the changing pattern (increase or decrease in 2011) of panel housing estates can be interpreted as a result of the global economic crisis that affected the conditions of the housing market.

Comparison between 2000 and 2011 in-migrant concentration patterns showed higher overall representation in 2000. Thirty five neighbourhoods had lower concentrations in their spatial units, whereas 18 territorial units experienced an increase in representation of in-migrants from other municipalities. The migrant concentration has most notably increased eastwards from the city centre and can be linked to the development of the housing market during the time of the economic crisis.

The authors of this study plan to expand this research and incorporate the analysis of 2016 and 2017. Such an addition would allow for the evaluation of post2011 development of residential patterns in Rīga, and the extent and importance of internal migration as a driving force in evoking changes in population distribution. The question of Residential Mobility would be a decent addition to the focus of this research. In such a case, it would be possible to assess whether short distance moves within post-socialist city borders are more or less impactful than internal migration. 


\section{Acknowledgement}

This study was supported by National Research Program Project No.VPP-IZM2018/1-0015.

\section{Kopsavilkums}

Iekšzemes migrācijai ir noteicoša nozīme iedzīvotāju izvietojuma attīstības veicināšanā. Migrācijas plūsmu raksturs var atšķirties un attīstîties dažādu politisku, ekonomisku un sociālu procesu ietekmē. Dažādu iedzìvotāju sastāva grupu izvietojuma īpatnības ir plaši pētītas postsociālistisko pilsētu kontekstā saistībā ar etnisko vai socioekonomisko segregāciju. Tomēr izvietojuma saikne pilsētās ar iekšzemes migrāciju tikusi mazāk pētīta. Šis pētījums vizualizē migrantu izvietojuma telpiskās atšķirības, parādot to telpisko koncentrāciju vai izkliedi starp Rīgas mikrorajoniem. Lai to panāktu, izmantoti 2000. un 2011. gada Tautas skaitǐšanas dati, kas tika ǵeoreferencēti un vizualizēti sešstūra šūnu režğa veidā. Katrā Rīgas mikrorajonā no citām pašvaldībām gada laikā iebraukušie iedzīvotāji tika attiecināti pret kopējo iebraucēju plūsmu visā pilsētā, izmantojot novietojuma koeficientu $(L Q)$. Pētījuma galvenie rezultāti norāda uz paaugstinātu migrantu koncentrāciju pilsētas centrālajā daḷā, kamēr perifērajā daḷā migrācijas aktivitāte bijusi krietni zemāka. Novērtējot izvietojuma attīstības iezīmes starp 2000. un 2011. gadu, redzams iekšzemes migrantu koncentrācijas samazinājums lielākajā daḷā pilsētas, kas lielā mērā saistāms ar globālo ekonomisko krīzi un mājokḷu tirgus īpatnībām. Izṇēmums gan ir vairāki daudzstāvu dzīvojamo apbūvju rajoni, kas atrodas austrumu virzienā no pilsētas centrālās daḷas, kur migrantu koncentrācija pat palielinājusies.

\section{References}

Brade, I., Herfert, G. and Wiest, K. (2009). Recent trends and future prospects of socio-spatial differentiation in urban regions of Central and Eastern Europe: A lull before the storm? Cities, 26 (5), 233 244.

Brown, L.A. and Chung, S.Y. (2006). Spatial segregation, segregation indices and the geographical perspective. Population, Space and Place, 12 (2), 125-143.

Gentile, M. and Tammaru, T. (2006). Housing and ethnicity in the post-soviet city: Ust'Kamenogorsk, Kazakhstan. Urban Studies, 43 (10), 1757-1778.

Gentile, M., Tammaru, T. and van Kempen, R. (2012). Heteropolitanization: Social and spatial change in Central and East European Cities. Cities, 29 (5), 291-299.

Kährik, A. and Tammaru, T. (2010). Soviet prefabricated panel housing estates: Areas of continued social mix or decline? The case of Tallinn. Housing Studies, 25 (2), 201-219.

Kontuly, T. and Tammaru, T. (2006). Population Subgroups Responsible for New Urbanization and Suburbanization in Estonia. European Urban and Regional Studies, 13 (4), 319-336.

Kovács, Z. and Herfert, G. (2012). Development pathways of large housing estates in postsocialist cities: An international comparison. Housing Studies, 27 (3), 324-342.

Krišjāne, Z. and Bērziņš, M. (2012). Post-socialist urban trends: New patterns and motivations for migration in the suburban areas of Rīga, Latvia. Urban Studies, 49 (2), pp. 289-306.

Krišjāne, Z. and Bērziňš, M. (2014). Intra-urban residential differentiation in the post-Soviet city: the case of Riga, Latvia. Hungarian Geographical Bulletin, 63 (3), 235-253.

Krišjāne, Z., Bērziņš, M. and Kratoviš, K. (2015). Occupation and ethnicity: Patterns of residential segregation in Riga two decades after socialism. In: Tammaru, T., Marcinczak, S., Van Ham, M. and Musterd, S. (eds.) Socio-economic Segregation in European Capital Cities: East Meets West. UK: Taylor and Francis Inc., 287-312.

Marcińczak, S., Musterd, S. and Stępniak, M. (2012). Where the grass is greener: Social segregation in three major Polish cities at the beginning of the 21 st century. European Urban and Regional Studies, 19 (4), 383-403.

Marcińczak, S., Tammaru, T., Novák, J., Gentile, M., Kovács, Z., Temelová, J., Valatka, V., Kährik, A., and Szabó, B. (2015). Patterns of socioeconomic segregation in the capital cities of fast- 
track reforming postsocialist countries. Annals of the Association of American Geographers, 105 (1), 183-202.

Novotný, L. and Pregi, L. (2015). Changes in ethnic structure of population in the light of recent trends of migration and natural reproduction. Geographica Pannonica, 19 (4), 194-211.

Reardon, S.F. and O'Sullivan, D. (2004). Measures of spatial segregation. Sociological Methodology, 34 (1), 121-162.

Sýkora, L. (2009). New socio-spatial formations: Places of residential segregation and separation in Czechia. Tijdschrift voor Economische en Sociale Geografie, 100 (4), 417-435.

Tammaru, T., Marcińczak, S., Van Ham, M. and Musterd, S. (eds.) (2015). Socio-economic Segregation in European Capital Cities: East Meets West. UK: Taylor and Francis Inc.

Temelová, J., Novák, J., Ouředníček, M. and Puldová, P. (2011). Housing estates in the Czech Republic after socialism: Various trajectories and inner differentiation. Urban Studies, 48 (9), 18111834.

Treija, S. and Bratuškins, U. (2014). Rīgas lielmēroga dz̄̄vojamo rajonu identitāte un attīstība. In: Rozenvalds, J. and Zobena, A. (eds.) Daudzveidīgās un main̄̄gās Latvijas identitātes, Rīga: LU Akadēmiskais Apgāds, 347-361.

\title{
DEFINING THE COMMUTING REGIONS OF LATVIA
}

\section{Latvijas svārstmigrācijas reǵionu noteikšana}

\author{
Toms Skadiňs \\ University of Latvia, Faculty of Geography and Earth Sciences \\ toms.skadins@lu.Iv
}

\begin{abstract}
In this research paper the geography of travel to work is analysed based on origin-destination commuting flows between municipalities. The aim of this study is to define work-related commuting regions of Latvia using the most recent data derived from the 2011 Population Census. The analysis demonstrates potential insights to be gained in defining regional patterns in the structure of work-related commuting flows using census data. The findings identify 17 commuting regions in Latvia and highlight the importance of Rìga in the context of the Latvian labour market. Two types of commuting regions were identified - mono-centric regions attracting large numbers of commuters in the main employment centre and poly-centric regions with more diversified travel-to-work flows.
\end{abstract}

Keywords: travel-to-work patterns, commuting behaviour, regions, census.

\section{Introduction}

In the last few decades, the processes of mobility (population movement) have had a tendency to become more diverse and more voluminous. Travel-to-work flows between municipalities represent a significant part of human mobility. Studies on the peculiarities of work-related commuting in post-socialist countries have mostly focused on the largest cities and their urban regions or agglomerations (Ahas et al. 2010; Novak and Sykora 2007; Novotny 2016). Country-wide or regional commuting patterns have been studied considerably less frequently (e.g. Klapka et al. 2013; Kraft et al. 2014; Marcinczak and Bartosiewicz 2018). The Statistical Bureau of Estonia has defined labour migration regions based on 2011 Census data (Statistics Estonia 2014). ESPON functional urban regions research has paid attention to all regional types 